\title{
STEM-CELL TREATMENT IN DISC DEGENERATION: WHAT IS THE EVIDENCE?
}

\author{
CÉLULAS TRONCO NO TRATAMENTO DE DOENÇA DEGENERATIVA DISCAL: \\ QUAL É A EVIDÊNCIA?
}

\section{CÉLULAS MADRE EN EL TRATAMIENTO DE DEGENERACIÓN DE DISCO: ¿CUAL ES LA EVIDENCIA?}

Manuela Peletti-Figueiró ${ }^{1}$, Pedro Guarise da Silva² ${ }^{2}$ Olívia Egger de Souza² ${ }^{2}$ Ana Paula Lambert ${ }^{3}$, Denise Cantarelli Machado ${ }^{4}$, Mariana Roesch-Ely ${ }^{5}$, João Antonio Pêgas Henrioues ${ }^{6}$, Asdrubal Falavigna?.

\begin{abstract}
To review the potential role of stem cells in treating degenerative disc disease of the intervertebral disc (IVD). A review was performed of articles from the Medline database concerning stem cells and degenerative disc disease (DDD). To discuss the data, the papers were classified as: review, in vitro, experimental, and clinical. The currently available treatments were basically for symptom reduction, not to revert the IVD degenerative process. The use of mesenchymal stem cells (MSC) is being proposed as an option of treatment for DDD. In vitro studies have shown that the MSC are able to differentiate into NP cells and that the MSC also reduce the inflammatory levels of the degenerated IVD. Besides, experimental studies demonstrated that the MSC remained viable when injected into the IVD, and that they were able to regenerate partially from the degenerated IVD and its structure. The few clinical studies found in the literature presented diverging results. The use of MSC is being widely studied and shows promising results for the treatment of DDD. Although many advances are being achieved in studies in vitro and experimental, there is a lack of clinical studies to prove the role of MSC in DDD management.
\end{abstract}

Keywords: Stem cells; Intervertebral disc degeneration; Spine; Mesenchymal stem cells; Intervertebral disc.

\section{RESUMO}

Revisar o potencial papel das células-tronco para o tratamento de doença degenerativa do disco intervertebral (IVD). Foi realizada uma revisão dos trabalhos da base de dados Medline em relação a células-tronco e doença degenerativa discal (DDD). Para fins de discussão dos dados, os trabalhos foram divididos em: revisão, in vitro, experimentais e clínicos. Os tratamentos disponíveis atualmente focam basicamente na redução dos sintomas, e não na reversão do processo degenerativo do DIV. O uso de células-tronco mesenquimais (CTM) vem sendo proposto como uma opção de tratamento para DDD. Estudos in vitro demonstraram que as CTM são capazes de se diferenciarem em células do NP e que as CTM também diminuem os níveis inflamatórios do DIV degenerado. Além disso, estudos experimentais demonstraram que as CTM permaneciam viáveis quando injetadas no DIV e que eram capazes de regenerar parcialmente do DIV degenerado e sua estrutura. Os poucos estudos clínicos presentes na literatura apresentam resultados divergentes. O uso de CTM esta sendo amplamente estudado e mostra resultados promissores para o tratamento da DDD. Embora muitos avanços venham sendo alcançados em estudos in vitro e experimentais, ainda faltam estudos clínicos para comprovar o papel das CTM no manejo da DDD.

Descritores: Células-tronco; Degeneração do disco intervertebral; Coluna vertebral; Células-tronco Mesenquimais; Disco intervertebral.

\section{RESUMEN}

Revisar el papel potencial de las células madre en el tratamiento de la enfermedad degenerativa del disco intervertebral (IVD). Se realizó una revisión de los artículos de la base de datos Medline sobre células madre y la enfermedad degenerativa del disco (DDD). Para fines de discusión de los datos, los trabajos se dividieron en: revisión, in vitro, experimentales y clínicos. Los tratamientos disponibles actualmente enfocan básicamente la reducción de los síntomas, y no la reversión del proceso degenerativo del IVD. El uso de células madre mesenquimales (MSC) se propone como una opción de tratamiento para DDD. Estudios in vitro demostraron que las MSC son capaces de diferenciarse en células NP y que las MSC también reducen los niveles inflamatorios de la IVD degenerado. Además, estudios experimentales demostraron que las MSC se mantuvieron viables cuando inyectadas en el IVD y que eran capaces de regenerarse parcialmente del IVD degenerado y su estructura. Los pocos estudios clínicos presentes en la literatura presentan resultados divergentes. El uso de MSC se está estudiando ampliamente y muestra resultados prometedores en el tratamiento de la DDD. Aunque se hayan logrado muchos avances en estudios in vitro y experimentales, aún faltan estudios clínicos para comprobar el papel de las MSC en el manejo de la DDD.

Descriptores: Células Madre; Degeneración del disco intervertebral; Columna vertebral; Células madre mesenquimales; Disco intervertebral.

1. PhD in Biotechnology, University of Caxias do Sul - Caxias do Sul, RS, Brazil.

2. Medical Student, University of Caxias do Sul - Caxias do Sul, RS, Brazil.

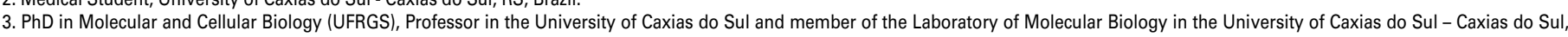
RS, Brazil.

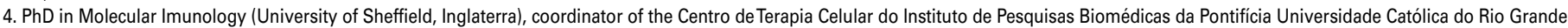
do Sul - Caxias do Sul, RS, Brazil.

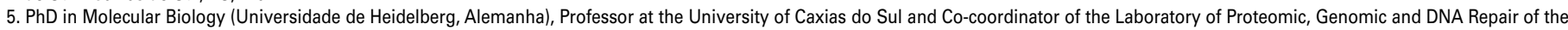
University of Caxias do Sul - Caxias do Sul, RS, Brazil.

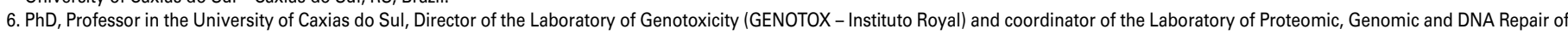
the University of Caxias do Sul - Caxias do Sul, RS, Brazil.

7. Professor of Neurosurgery, Dean of the Medical School of the University of Caxias do Sul, Caxias do Sul, RS, Brazil. 


\section{INTRODUCTION}

Degenerative disc disease (DDD) is a common and natural process in the human spine. This degeneration occurs progressively and can affect the biomechanics, stability, and neurological function of the spine ${ }^{1}$. In the United States (US) almost 300.000 surgeries are performed every year due to DDD, with the costs related to the surgical procedures rising to 50 billion dollars annually². Overall, 1.5 million disc surgeries are performed worldwide every year ${ }^{3}$. Annually, approximately 5 of 1000 persons will present sciatica due to disc disorders ${ }^{4}$, which are the major cause of chronic low-back pain in the modern world ${ }^{5}$.

Nowadays, degeneration of the intervertebral disc (IVD) is regarded as an irreversible phenomenon. The treatment options involve basically non-surgical (physical therapy, nerve root blocks) and surgical strategies (disc excision and arthrodesis), which are effective only in symptomatic relief and may actually accelerate the degenerative process in adjacent levels ${ }^{6}$. Recent studies demonstrated the potential of stem cell treatment to regenerate or repopulate the degenerated IVD ${ }^{7-9}$.

The goal of this study is to review the potential of stem cells as a treatment option for DDD, discussing the actual role of the stem cell treatment.

\section{Physiopathology of Disc Degeneration}

The human spine is composed by 23 IVD that separate the vertebrae and provide flexibility. They account for 20 to $30 \%$ of the length of the spine and increase in size on progression from the cervical to the lumbar spine ${ }^{10}$. In addition to flexibility the IVD have the function of stability and support loads during exercise. The IVD structure consists basically in a central part called the nucleus pulposus derived from notochord, which is surrounded by the annulus fibrosus derived from mesenchymal tissue ${ }^{10}$. The nucleus pulposus (NP) is rich in proteoglycan and water whereas the annulus fibrosus is rich in collagen, especially type $\mathrm{I}, \mathrm{II}, \mathrm{VI}$ and $I \mathrm{X}^{11,12}$.

The composition of the IVD varies with the level of the spine, the collagen content in the nucleus being highest in the cervical discs and lowest in the lumbar discs, whereas the proteoglycan content shows the opposite trend ${ }^{13}$.

In the mature NP, the proteoglycan aggregates are important to retain water and restricting the water flux influences the response of the tissue to loads delivered in the spine ${ }^{11}$. With ageing principally in the nucleus there is a decrease of proteoglycan aggregates and an increase of nonaggregating aggrecan because of proteolytic degradation ${ }^{14,15}$. Thus, with age the ability of resist compressive loading declines.

In the annulus fibrosus the collagen fibrils are oriented in sheets around the NP. The key function of this structure is to retain the NP, taking up and distributing the load exerted by this tissue during various types of exercise ${ }^{11}$.

During life many changes occur in the composition of the extracellular matrix including notochordal cell loss, mesenchymal cell senescence, loss of the vasculature and calcification of the vertebral endplates, which alter or decrease the synthetic capabilities of the disc cells ${ }^{10}$. Nuclear cell density decreases with age throughout life, whereas annular cellularity reaches a plateau after the age of 50 years ${ }^{16}$. The normal turnover capability is impaired in the disc matrix and degeneration products accumulate ${ }^{10}$.

The IVD degeneration and its structural changes result from this continuum catabolism occurring in the extracellular matrix associated with the incapacity of replace the impaired collagen fibers and aggrecan with new molecules during life. The IVD appears incapable of intrinsic repair in the adult, but it is the dream of physicians to be able to induce such biologic repair ${ }^{17}$.

\section{Cell-Based Therapy for Intervertebral Disc Degeneration}

Nowadays, surgical and non-surgical therapies to manage IVD degeneration focus only on symptom relief. In recent years, as the understanding of the molecular and cellular events involved in disc degeneration has improved, the idea of manipulating the cellular content of the disc to achieve a beneficial outcome has grown ${ }^{6,18}$.

One treatment option is the use substances in order to stimulate the existing disc cells to increase production of proteoglycan. However, due to the relative accelularity of the degenerated disc it may not be sufficient to achieve a good result. An option for that issue is to introduce in the degenerated disc cells capable of producing appropriate matrix in an attempt to recover the biomechanical properties of the disc ${ }^{6}$.

Nishimura et al. ${ }^{19}$ performed the transplantation of autologous NP tissue into denucleated rat discs, where it was shown to slow the progression of degeneration. However, this cell source has practical limitations in the clinical setting due to the necessity of damaging an adjacent disc, likely inducing degeneration in this level. By contrast, adult mesenchymal stem cells (MSC) are easily procured by bone marrow aspiration, and are more capable of adapting successfully to the environment of the disc and therefore of achieving a differentiated state appropriate for long-term matrix synthesis ${ }^{6}$.

\section{Characteristics of Mesenchymal Stem Cells}

MSC are undifferentiated, multipotent cells that have the ability to differentiate into a number of cell types, including bone, cartilage, fat, muscle and tendons, depending on the environment and biologic signals provided. It has already been established that MSC can be pushed into chondrogenic or perhaps even discogenic pathways and are capable of expressing aggrecan and Type II collagen in large quantities ${ }^{20}$. Another advantage is the fact that MSC can be obtained from many autologous sources including bone marrow and fat without significant morbidity or immunogenic response and can be easily expanded in cultures ${ }^{21}$.

\section{In Vitro Studies with Stem Cells and Disc Degeneration}

It was already known that MSC were able to differentiate into chondrocyte-like cells ${ }^{22}$. Due to the fact that NP and chondrocytes have similar characteristics, it is reasonable to assume that MSC could also be able to differentiate into NP-like cells ${ }^{23,24}$.

Risbud et al. ${ }^{12}$ demonstrated that rat MSC when exposed to hypoxia and transforming growth factor- $\beta$ are able to differentiate into a phenotype consistent with that of the NP via mitogen-activated protein kinase signaling pathways. Using different methods, other authors also demonstrated that MSC are able to differentiate into NP-like cells that could be used in cell-based tissue engineering therapies for IVD regeneration ${ }^{25-32}$.

Blanco et al. $^{33}$ performed the isolation and characterization of MSC from human degenerated disc. They found that the degenerated NP contains MSC and that those cells are extremely similar to those found in the bone marrow. These findings suggest that DDD could be treated by cell therapy, injecting differentiated cultured MSC into NP-like cells, and stimulating the MSC already present in the NP.

One of the possibilities to explain why some patients with DDD present more pain than others is the development of intradiscal inflammation. Bertolo et al. ${ }^{34}$ studied the immunosuppressive influence of the MSC in fragments of the IVD of patients with DDD. They found that $70 \%$ of the patients had a reduction in IgG production and the proliferation of peripheral blood lymphocytes was also reduced when MSC were present. This effect in reducing inflammation shows that the potential role of MSC for DDD goes beyond the ability to repopulate the IVD.

\section{Experimental Studies with Stem Cells and Disc Degeneration}

After demonstrating that MSC are able to differentiate into NP-like disc cells, in vivo studies were necessary to evaluate the efficacy and safety of this therapeutic option in degenerated discs.

Crevensten et al. ${ }^{35}$ studied the viability of MSC injected in rat coccygeal discs; 14 days after injection a decrease in the number of MSC labeled with fluorescence was observed. However, twenty-eight days after injection the number of MSC rose to the initial number of cells with $100 \%$ viability.

Bendtsen et al. ${ }^{36}$ induced disc degeneration in minipigs and injected hydrogels without MSC and hydrogels loaded with autologous MSC. They found that MSC and hydrogel therapy are able to partly regenerate the IVD and maintain perfusion and permeability of the vertebral endplate and subchondral bone. Another author performed the transplantation of human MSC into minipigs with DDD and found that those cells survived in the porcine disc for at least 6 months and expressed typical chondrocyte markers suggesting differentiation toward disc-like cells, demonstrating the possibility of xenotransplantation ${ }^{37}$. Some authors also reported the increase in disc height with the use of MSC compared to control groups $38-40$.

The in vivo studies performed in rats and minipigs were able to 
demonstrate that MSC are able to survive and differentiate when injected into the degenerated IVD and have the potential to restore its normal function and structure. However, those results are limited by its models of degeneration that trigger rapid degeneration of the IVD which are not equivalent to slow degeneration that occurs in human disc degeneration ${ }^{41}$. Also, the tail disc of rats and pigs is not submitted to the same static and dynamic load to which human discs are exposed ${ }^{42,43}$.

\section{Clinical Studies with Stem Cells and Disc Degeneration}

There are a few clinical studies using stem cells in DDD in the literature.

Haufe and Mork ${ }^{7}$ found no improvement in the lower back after one year in 10 patients with DDD submitted to injection of hematopoietic precursor stem cells obtained from the patient's bone marrow. However, those authors did not perform any culture or expansion of the stem cells prior to the injection. In addition, they also submitted the patients to a 2-week course of hyperbaric oxygen therapy after the cells were injected.

Yoshikawa et al. ${ }^{9}$ studied the effect of MSC in two patients with DDD; they found that two years after the initial procedure the symptoms had improved in both patients and the rates of the Visual Analog Scale score for low back pain have decreased 38\% in one case and $18 \%$ in the second patient. In both patients after two years radiograph and computed tomography confirmed that the intervertebral vacuum phenomenon improved.

\section{REFERENCES}

1. Roh JS, Teng AL, Yoo JU, Davis J, Furey C, Bohlman HH. Degenerative disorders of the lumbar and cervical spine. Orthop Clin North Am. 2005;36(3):255-62.

2. Koebbe CJ, Maroon JC, Abla A, El-Kadi H, Bost J. Lumbar microdiscectomy: a historical perspective and current technical considerations. Neurosurg Focus. 2002;13(2):E3

3. PeulWC, van Houwelingen HC, van den HoutWB, Brand R, Eekhof JA, Tans JT, Thomeer et al. Sur gery versus prolonged conservative treatment for sciatica. N Engl J Med. 2007:356(22):2245-56

4. Bakhsh A. Long-term outcome of lumbar disc surgery: an experience from Pakistan. $\mathrm{j}$ Neurosurg Spine. 2010;12(6):666-70.

5. Katz JN, Stucki G, Lipson SJ, Fossel AH, Grobler LJ, Weinstein JN. Predictors of surgical outcome in degenerative lumbar spinal stenosis. Spine (Phila Pa 1976) 1999.24(21).2229-33.

6. Acosta FL Jr, Lotz J, Ames CP.The potential role of mesenchymal stem cell therapy for intervertebral disc degeneration: a critical overview. Neurosurg Focus. 2005 Sep 15;19(3):E4.

7. Haufe SM, Mork AR. Intradiscal injection of hematopoietic stem cells in an attempt to rejuvenate the intervertebral discs. Stem Cells Dev. 2006;15(1):136-7.

8. Orozco L, Soler R, Morera C, Alberca M, Sánchez A García-Sancho J. Intervertebral disc repair by autologous mesenchymal bone marrow cells: a pilot study. Transplantation. 2011;92(7):822-8.

9. Yoshikawa T, Ueda Y, Miyazaki K, Koizumi M, Takakura Y. Disc regeneration therapy using marrow mesenchymal cell transplantation: a report of two case studies. Spine (Phila Pa 1976). 2010:35(11):E475-80.

10. Roughley PJ. Biology of intervertebral disc aging and degeneration: involvement of the extracellular matrix. Spine (Phila Pa 1976). 2004;29(23):2691-9.

11. Feng $H$, Danfelter $M$, Strömqvist $B$, Heinegård $D$. Extracellular matrix in disc degeneration. J Bone Joint Surg Am. 2006;88(Suppl 2):25-9

12. Risbud MV, Albert TJ, Guttapalli A, Vresilovic EJ, Hillibrand AS, Vaccaro AR, et al. Differentiation of mesenchymal stem cells towards a nucleus pulposus-like phenotype in vitro: implications for cell-based transplantation therapy. Spine (Phila Pa 1976). 2004;29(23):2627-32.

13. Scott JE, Bosworth TR, Cribb AM, Taylor JR. The chemical morphology of age-related changes in human intervertebral disc glycosaminoglycans from cervical, thoracic and lumbar nucleus pulposus and annulus fibrosus. J Anat. 1994:184(Pt 1):73-82.

14. Jahnke MR, McDevitt CA. Proteoglycans of the human intervertebral disc. Electrophoretic heterogeneity of the aggregating proteoglycans of the nucleuspulposus. Biochem J. 1988;251(2):347-56

15. Johnstone B, Bayliss MT. The large proteoglycans of the human intervertebral disc. Changes in their biosynthesis and structure with age, topography, and pathology. Spine (Phila Pa 1976). 1995;20(6):674-84

16. Vernon-Roberts $B$, Moore RJ, Fraser RD. The natural history of age-related disc degeneration: the influence of age and pathology on cell populations in the L4-L5 disc. Spine (Phila Pa 1976). 2008;33(25):2767-73.

17. Guyer RD, Ohnmeiss DD. Intervertebral disc prostheses. Spine (Phila Pa 1976). 2003;28(15 Suppl):S15-23

18. Freemont AJ, Watkins A, Le Maitre C, Jeziorska M, Hoyland JA. Current understanding of cellular and molecular events in intervertebral disc degeneration: implications for therapy. J Pathol. 2002:196(4):374-9.

19. Nishimura K, Mochida J. Percutaneous reinsertion of the nucleus pulposus. An experimental study. Spine (Phila Pa 1976). 1998;23(14):1531-8.

20. Anderson DG, Risbud MV, Shapiro IM, Vaccaro AR, Albert TJ. Cell-based therapy for disc repair. Spine J. 2005;5(Suppl6):297S-303S.

21. Bartholomew A, Sturgeon C, Siatskas M, Ferrer K, Mclntosh K, Patil S, et al. Mesenchymal stem cells suppress lymphocyte proliferation in vitro and prolong skin graft survival in vivo. Exp Hematol. 2002;30(1):42-8.

22. Wakitani S, Imoto K, Yamamoto T, Saito M, Murata N, Yoneda M. Human autologous culture expanded bone marrow mesenchymal cell transplantation for repair of cartilage defects in osteoarthritic knees. Osteoarthritis Cartilage. 2002:10(3):199-206.

23. Horner HA, Roberts S, Bielby RC, Menage J, Evans H, Urban JP. Cells from different regions of the intervertebral disc: effect of culture system on matrix expression and cell phenotype. Spine (Phila Pa 1976). 2002;27(10):1018-28.
Orozco et al. ${ }^{8}$ performed injected autologous MSC in 10 patients with confirmed DDD; they found that after the injection of the MSC the patient had a rapid improvement in pain and disability at 3 months, followed by a modest improvement within 6 and 12 months after injection. There appeared to be no improvement in disc height. However the water content of the disc was significantly elevated at 12 months. This author also pointed out that those results are important, since intervention is simpler, more conservative, preserves normal biomechanics, and does not require surgery or patient hospitalization? .

\section{FINAL CONSIDERATIONS}

IVD degeneration is a natural process throughout human life and it involves many changes in the composition of the disc structure. Reduction of cellularity and the consequent changes in extracellular matrix are key factors in the physiopathology of the degenerative process. The use of cell therapy for IVD degeneration has been studied as a potential treatment option for this condition. This therapy is supposed to allow treatment of patients with back pain, avoiding extensive surgeries, with less expense, besides leading to less morbidity. The use of MSC is being widely studied and shows a great potential in the repopulation on the NP. Although many advances have been made and many experimental models have shown that MSC are able to regenerate the disc, so far there are few clinical studies measuring the effect of those cells in humans with degenerative disc disease.

24. Gruber HE, Stasky AA, Hanley EN Jr. Characterization and phenotypic stability of human disc cells in vitro. Matrix Biol. 1997;16(5):285-8

25. Yamamoto Y, Mochida J, Sakai D, Nakai T, Nishimura K, Kawada H, et al. Upregulation of the viability of nucleus pulposus cells by bone marrow-derived stromal cells: significance of direct cell-to-cell contact in coculture system. Spine (Phila Pa 1976). 2004:29(14):1508-14.

26. Richardson SM, Walker RV, Parker S, Rhodes NP, Hunt JA, Freemont AJ, et al. Intervertebral disc cell-mediated mesenchymal stem cell differentiation. Stem Cells. 2006;24(3):707-16.

27. Vadalà G, Studer RK, Sowa G, Spiezia F, lucu C, Denaro V, Gilbertson LG, et al. Coculture of bone marrow mesenchymal stem cells and nucleus pulposus cells modulate gene expression profile without cell fusion. Spine (Phila Pa 1976). 2008:33(8):870-6.

28. Le Visage C, Kim SW, Tateno K, Sieber AN, Kostuik JP, Leong KW. Interaction of human mesenchymal stem cells with disc cells: changes in extracellular matrix biosynthesis. Spine (Phila Pa 1976). 2006;31(18):2036-42.

29. Gruber HE, Deepe R, Hoelscher GL, Ingram JA, Norton HJ, Scannell B, et al. Human adipose-derived mesenchymal stem cells: direction to a phenotype sharing similarities with the disc, gene expression profiling, and coculture with human annulus cells. Tissue Eng Part A. 2010;16(9):2843-60

30. Sobajima S, Vadala G, Shimer A, Kim JS, Gilbertson LG, Kang JD. Feasibility of a stem cell therapy for intervertebral disc degeneration. Spine J. 2008:8(6):888-9.

31. SvanvikT, Henriksson HB, Karlsson C, Hagman M, Lindahl A, Brisby H. Human disk cells from degenerated disks and mesenchymal stem cells in co-culture result in increased matrix production. Cells Tissues Organs. 2010;191(1):2-11.

32. Yang SH, Wu CC, Shih TT, Sun YH, Lin FH. In vitro study on interaction between human nucleus pulposus cells and mesenchymal stem cells through paracrine stimulation. Spine (Phila Pa 1976). 2008;33(18):1951-7.

33. Blanco JF, Graciani IF, Sanchez-Guijo FM, Muntión S, Hernandez-Campo P, Santamaria C, et al. Isolation and characterization of mesenchymal stromal cells from human degenerated nucleus pulposus: comparison with bone marrow mesenchymal stromal cells from the same subjects. Spine (Phila Pa 1976). 2010:35(26):2259-65.

34. Bertolo A, Thiede T, Aebli N, Baur M, Ferguson SJ, Stoyanov JV. Human mesenchymal stem cell co-culture modulates the immunological properties of human intervertebral disc tissue fragments in vitro. Eur Spine J. 2011;20(4):592-603.

35. Crevensten G, Walsh AJ, Ananthakrishnan D, Page P, Wahba GM, Lotz JC, et al. Intervertebral disc cell therapy for regeneration: mesenchymal stem cell implantation in rat intervertebral discs. Ann Biomed Eng. 2004;32(3):430-4.

36. Bendtsen M, Bünger CE, Zou X, Foldager C, Jørgensen HS. Autologous stem cell therapy maintains vertebral blood flow and contrast diffusion through the endplate in experimental intervertebral disc degeneration. Spine (Phila Pa 1976). 2011:36(6):E373-9.

37. Henriksson HB, Svanvik T, Jonsson M, Hagman M, Horn M, Lindahl A, et al. Transplantation of human mesenchymal stems cells into intervertebral discs in a xenogeneic porcine model. Spine (Phila Pa 1976). 2009;34(2):141-8.

38. Yang H, Wu J, Liu J, Ebraheim M, Castillo S, Liu X, et al. Transplanted mesenchymal stem cells with pure fibrinous gelatin-transforming growth factor-beta1 decrease rabbit intervertebral disc degeneration. Spine J. 2010;10(9):802-10.

39. Feng G, Zhao X, Liu H, Zhang H, Chen X, Shi R, et al. Transplantation of mesenchymal stem cells and nucleus pulposus cells in a degenerative disc model in rabbits: a comparison of 2 cell types as potential candidates for disc regeneration. J Neurosurg Spine. 2011;14(3):322-9.

40. Sakai D, Mochida J, Iwashina T, Hiyama A Omi H, Imai M, et al. Regenerative effects of transplanting mesenchymal stem cells embedded in atelocollagen to the degenerated intervertebral disc. Biomaterials. 2006;27(3):335-45

41. Rousseau MA, Ulrich JA, Bass EC, Rodriguez AG, Liu JJ, Lotz JC. Stab incision for inducing intervertebral disc degeneration in the rat. Spine (Phila Pa 1976). 2007:32(1):17-24.

42. An HS, Masuda K. Relevance of in vitro and in vivo models for intervertebral disc degeneration. J Bone Joint Surg Am. 2006;88(Suppl 2):88-94.

43. Lotz JC, Ulrich JA. Innervation, inflammation, and hypermobility may characterize pathologic disc degeneration: review of animal model data. J Bone Joint Surg Am. 2006;88(Suppl 2):76-82. 